\title{
Closing and cloning in open-end mutual funds
}

\author{
Hsiu-Lang Chen ${ }^{\mathrm{a}, *}$, Sheldon Gao ${ }^{\mathrm{b}}$, Xiaoqing $\mathrm{Hu}^{\mathrm{a}}$ \\ ${ }^{a}$ Department of Finance, University of Illinois at Chicago, Chicago, IL 60607, USA \\ ${ }^{\mathrm{b}}$ China Universal Asset Management, 1 Harbor View Street, Central, Hong Kong
}

This version: November 8, 2011

\begin{abstract}
Using an unique dataset, we document that only those closed funds for which no new fund is subsequently launched continuously deliver positive abnormal returns. This suggests the existence of an optimal fund scale. In spite of the potential diseconomies of scale, a non-trivial proportion of closed funds have new funds cloned-the scale motive would not be a complete explanation for the closure. When managers of closed funds clone new funds, they receive greater public attention and thus can attract more fund flows and charge higher fees. Furthermore, better-performing closed fund managers attract more fund flows to their new siblings, making the closure an effective mechanism to extract economic rents. Overall, we find that closing and cloning is an attractive strategy for funds seeking to increase their management fees and funds with more managers in place. Aspects of the closed fund family also affect the launch decision of new siblings.
\end{abstract}

JEL classification: G02; G23

Keywords: Mutual funds; Fund closing; Fund cloning

*Corresponding author. Tel.: +1 312355 1024; fax: +1 3124137948.

E-mail addresses: hsiulang@uic.edu (H. Chen), sheldon.gao@gmail.com (S. Gao +852-

3983-5600), hu_xiaoqing@yahoo.com (X. Hu). 


\section{Introduction}

The mutual fund industry plays an increasingly significant role in the U.S. economy and world financial markets. Registered investment companies managed less than $\$ 150$ billion in 1980 , but this figure has grown to over $\$ 11.2$ trillion by the end of 2006 . While money is continuously pouring into mutual funds, more and more mutual fund companies are trying to shut their doors to new investors and/or all investors. ${ }^{1}$ In this paper we explore the motivation for these closures.

A potentially important motivation for fund closures relates to optimal portfolio scale. As Perold and Salomon (1991) argue, while there are advantages to increased scale such as more resources for research and lower expense ratios, a large asset base erodes fund performance due to trading costs associated with liquidity and/or price impact effects. For instance, while a small fund can easily put all of its money in its best ideas, a lack of liquidity forces a large fund to invest in its not-so-good ideas and to take larger positions per stock than is optimal, thereby eroding performance. In addition, Stein (2002) argues that in the presence of hierarchy costs, small organizations are likely to outperform large ones at tasks that involve the processing of soft information which cannot be directly verified by anyone other than the agent who produces it. In the context of mutual funds, this means that in large funds with hierarchies, managers may end up expending more effort generating quantitative measures (i.e., hard information) in order to convince others to implement an investment idea than they would if they were in control of their own smaller funds. After controlling for effects of other fund characteristics on performance in

\footnotetext{
${ }^{1}$ The closure initiative typically comes from the fund manager herself, or the fund management team. It is a gradual process when fund managers are faced with lots of net inflows and are starting to realize that. The fund has to go through a formal process and the shareholders have to be notified. At that point, the legal department, product management, marketing, and senior executives get involved. It becomes a fund family decision and ultimately needs an approval from the fund board. Up to that point, it would be rare to turn down such a request. Generally speaking, existing shareholders in a fund can continue to invest in funds closed to new investors. In addition, employees saving in 401(k) plans typically can invest in a closed-to-new fund so long as the fund is an option in their retirement plan, regardless of whether they have invested in that fund before.
} 
the regression framework proposed by Fama and MacBeth (1973), Chen, Hong, Huang, and Kubik (2004) provide empirical evidence that, indeed, scale erodes fund performance through the interaction of liquidity and organizational diseconomies.

Consistent with the above literature, many closed funds cite increasing size as the main reason for closing the fund to new investors. ${ }^{2}$ These funds constitute a self-selected sample of managers that may be affected by decreasing returns to scale. As such, closure decisions of these funds allow us to investigate whether mutual fund performance is in fact scalable over time. Indeed, the decreasing returns to scale in active portfolio management is a crucial assumption in an influential rational model proposed by Berk and Green (2004). Under this assumption, they derive that fund flows rationally respond to past performance even though performance is not persistent and investments with active managers do not outperform passive benchmarks on average. Chen et al. (2004) document the cross-sectional snapshot that the fund returns decline with fund size. However, the literature provides no evidence on the time-series evolution of a fund's size on the fund performance. This study makes an attempt to provide evidence in this direction. Since whether a firm is able to raise inputs for more outputs is hardly observable, it is common in the literature to use cross-sectional data to examine economies of scale, which, however, is a time-series issue per se. ${ }^{3}$ The study of closed funds of which managers selfdeclare to be affected by decreasing returns to scale makes this attempt likely.

\footnotetext{
${ }^{2}$ When Fidelity closed four funds, including its star attraction the $\$ 65.2$ billion Contrafund, in April 2006, its spokeswoman said that the closure is "best for shareholders." (See "Fidelity Looks to Protect Performance, Will Close 2 More Big Mutual Funds,” Jennifer Levitz, Wall Street Journal, April 15, 2006.) Similarly, in the announced closure of their Artisan International Small Cap Fund, the fund managers stated that "The closing is intended to limit the growth of the Fund's assets and to preserve the management team's ability to manage the Fund effectively for existing shareholders." (See "Artisan International Small Cap Fund Closed to New Investors," Business Wire, September 26, 2003).

${ }^{3}$ A production process is theoretically said to exhibit economies (diseconomies) of scale over a particular range of output per unit of time if the long-run average production cost over this range falls (rises) as output rises. Thus, an individual firm's primary concern is whether the output can be scaled over time to reach the lowest long-run average production cost. In the literature of economies of scale, however, researchers, for example, Christensen and Greene (1976), Murray and White (1983), Brush and Karnani (1996), and Trostel (2004), mainly rely on the analysis of
} 
Prior studies such as Smaby and Fizel (1995), Manakyan and Liano (1997), and Zhao (2004) find no evidence that funds earn superior returns relative to their benchmarks following their closure. By controlling mutual fund investment styles, neither did Bris, Gulen, Kadiyala, and Rau (2007) find any evidence that closed funds generate positive returns after the closure. They also show the cross-sectional snapshot that the combination of a large fund size and a high inflow has a significant negative impact on performance. However, if mutual fund performance is indeed scalable, why can't these closed funds with superior pre-closure performance maintain their upbeat record by naturally restricting the fund size/flows over the post-closure period? Without resolving this puzzle, it is premature to close the chapter of optimal portfolio scale in the mutual fund literature.

Coincidently, however, some new sibling funds are subsequently launched for a closed fund by the fund family even in the same investment objective. Thus, like characters in the latest installment of "Star Wars," mutual funds managers face their own version of Clone Wars. This new episode casts doubt on the idea that the motivation behind funds closing to new investors is solely due to diseconomies of scale in fund size. ${ }^{4}$ We therefore seek to find potential clues to the motives behind funds’ closure decisions. In this paper, we define a new sibling fund as a fund that is initiated under the same manager of the closed fund during the closing period, while a cloned fund is a sibling fund with the same investment objective.

In a mutual fund tournament, portfolio managers compete for better performance, greater fund inflows, and ultimately, higher compensation. Since fund managers are compensated based

cross-sectional data to make the inference. Since the limit of a firm being able to raise inputs for more outputs is not commonly observable, it is difficult to provide the direct evidence of economies of scale based on the analysis of the firm's time-series data. However, this is not the case in this study because we analyze closed funds which declare themselves as facing the adverse scale effect on fund performance. If diseconomies of fund scale exist, we should be able to observe that a closed fund can preserve whatever its performance is by freezing the fund asset size.

${ }^{4}$ The media also questions the motivation behind funds cloning a new fund. For example, Tom Lauricella, "Mutual Funds Become Clone Wars,” Wall Street Journal, May 25, 2005, and Tom Lauricella, “Same Managers! Same Strategy! New Fund?” Wall Street Journal, July 20, 2004. 
upon assets under management, they are not likely to choose to keep their funds small just because larger funds tend to hurt returns to their investors (who may not be aware of the downside of fund scale). ${ }^{5}$ Furthermore, as many studies document, the majority of active mutual funds cannot outperform passive index funds and better performing funds' returns are hardly persistent. Given this environment, fund managers might naturally turn to non-performancebased mechanisms to differentiate themselves from their peers. For example, Sirri and Tufano (1998) document that the performance-flow relationship is most pronounced among funds with higher marketing efforts. Although marketing effort results in higher fees, it lowers consumers' search costs. In a related money market fund industry, Christoffersen (2001) documents that over half of money fund managers voluntarily waive fees they have contractual rights to claim. The paper argues that low-performing funds waive fees to improve their relative performance ranks and to attract increased fund flows.

Shutting out new investors could be another non-performance-based mechanism to make closed funds stand out from the crowd. Mutual funds' decision to shut out new investors can signal good governance or show a willingness to honor prior commitments, ${ }^{6}$ earning the fund increased trust of fund shareholders as well as potential investors. It is a credible signal because it is costly in terms of foregone fees from additional inflows. Thus, by closing the existing fund, fund managers receive greater public attention, which can lead to more fund flows and higher fees in a new launched sibling fund. The closure decision may therefore intend to enhance the fund's reputation in an effort to increase future businesses, but not necessarily to serve the best

\footnotetext{
${ }^{5}$ Not everyone agrees upon on this statement. For example, Growth Fund of America became the first mutual fund to pass $\$ 200$ billion assets but still remains open. Please see Diya Gullapalli, "Is a \$200 Billion Star a Good Thing?” Wall Street Journal, October 13, 2007. While increasing inflows will undoubtedly make management's job more difficult going forward, Capital Research \& Management, which runs American Funds, has shown its multiple portfolio counselor system to be quite adept at managing high volumes of assets.

${ }^{6}$ When new mutual funds start to establish themselves, they might commit to close to new investors as the fund's assets reach a certain size. However, we do not rule out the possibility that mutual funds might herd in closing decisions since they don't want to act differently from other peer managers (Scharfstein and Stein (1990)).
} 
interest of fund shareholders. In this study we analyze these closed funds for which new sibling funds are cloned during the closing period in hopes of fully understanding why mutual funds shut out new investors.

Between January 1995 and December 2004, 228 funds closed to new investors. This involves 188 individual equity funds because some funds close more than once. We find that overall, closed funds do not generate significantly positive size- and objective-adjusted returns after the closure. Rather, only those closed funds for which no new funds are subsequently launched continuously deliver significantly positive size- and objective-adjusted returns. In addition, the total net asset value of these closed funds continues to grow, partially due to the good performance. This new finding suggests the existence of an optimal fund scale, that is, a mutual fund can continue to offer high performance by closing itself to investors once it reaches a certain asset size. This finding fills in the piece of time-series evidence missing in the previous literature of diseconomies of fund scale. Surprisingly, and economic significantly, however, 70 closed-fund managers clone independent sibling funds in the same investment objective. These closed funds exhibit neither significant size- and objective-adjusted returns nor growth in assets after the closure, casting doubt on the optimal scale being the unique explanation for the closing decision. By comparing the characteristics and performance of closed funds with and without new siblings, we shed light on other explanations. Further, by carefully examining the newly cloned funds versus other newly established funds, we find evidence that the closure decision can be an effective non-performance-based mechanism to attract more fund flows and raise expense ratios in the cloned funds.

In summary, our paper makes a number of contributions to the literature. First, we document that closed funds without new sibling funds continuously outperform the objective- 
and size-matched benchmark after the closure and thus their total net assets can grow internally. This provides evidence that mutual fund performance is in fact scalable. Second, we identify the interesting phenomenon that while some mutual funds close, they clone funds in the same investment objective. We conjecture that in addition to resolving diseconomies of scale, closed funds might use the closure to stand out from the crowd amidst stiff competition in the mutual fund industry in an effort to charge higher fees and generate larger fund flows in their cloned funds. We provide evidence to support our conjecture. Third, we present a more complete picture of fund closure policy based on more comprehensive data than the data used in prior studies. Bris et al. (2007), for example, construct their sample by primarily searching the Factiva news archive using keywords. Inevitably, a more famous or successful fund is more likely to appear in news reports and thus analyses based on these closed funds could be biased. In contrast, we systematically identify the complete population of closed funds using a customized data set from Morningstar Inc., and supplemented it using Morningstar's historical monthly Principia CD-ROMs. The resulting sample outnumbers those used in prior studies.

Our paper proceeds as follows. Section 2 provides a summary of the data and the characteristics distribution of closed funds. Section 3 analyzes the performance of closed funds after their closure. Section 4 discusses potential motivations behind mutual funds' close-andclone decisions, and using logistic regressions, Section 5 tests these motivations with a control of factors at the fund family level and market conditions that might simultaneously affect the clone decision. Finally, Section 6 concludes the paper. 


\section{The data}

Our primary data on mutual funds come from Morningstar's mutual fund database for the period from January 1995 to December 2004. We restrict our analysis to diversified U.S. equity mutual funds by excluding bond, international, and specialized sector funds from our sample. Specifically, we select mutual funds from the Morningstar database that have reported one of the following investment objectives at any point in their lives: Large Blend, Large Growth, Large Value, Mid-Cap Blend, Mid-Cap Growth, Mid-Cap Value, Small Blend, Small Growth, and Small Value. For a fund to be in our sample, it must report information on assets under management. Additionally, we require that a closed fund have at least one year of reported returns following its closure, because we want to exclude funds closing to investors due to merger or liquidation. Because funds can close and then reopen, and in some cases they do so repeatedly, we must use Morningstar's historical monthly Principia CD-ROMs to extract comprehensive closing and reopening dates. ${ }^{7}$ To avoid double-counting, we include a fund with multiple share classes in the closed fund sample only when all share classes of the fund are closed. We are not interested in funds that are closing solely aiming at launching new share classes before reopening. In our analysis, fund-level monthly returns, expense ratios, and 12b-1 fees are obtained by averaging corresponding statistics across different share classes while the oldest share class of a fund is used to calculate the fund's age. A fund's total net asset value (TNA) is the aggregate TNA of its all share classes. Our final sample has 228 closing events between January 1995 and December $2004 .^{8}$

\footnotetext{
${ }^{7}$ Morningstar's up-to-date database does not provide historical closing or reopening dates. When Fidelity's LowPriced Stock Fund closed to new investors on December 31, 2003, it marked the fifth time since 1992 that the fund had shut its doors. Before the first quarter of 1999, Morningstar's Principia CD-ROMs are available on a quarterly basis only. Whenever a fund is recorded as a closed fund in the periodical Principia CD-ROMs, we assume that the fund is closed at the beginning of the period.

${ }^{8}$ Seven are hard closing events, in which funds close to both existing shareholders and new investors, while the remaining 221 are soft closing events, in which funds close to new investors only. Since our main focus is to
} 


\subsection{Basic statistics}

Table 1 reports summary statistics for our sample. Panel A reports data on the distribution of fund closings by year. Fund closures are a relatively recent phenomenon, with 43\% of our sample funds closing in the 2002 to 2004 period. The largest proportion of fund closures (20\%) occurred during 2004 following the strong rebound in stock markets in 2003; for instance, the Russell 2000 Index gained 47.25\%. Although most closed funds cite their increasing size as the main reason they closed to investors, it is not unusual for a closed fund to create a new sibling fund after its closure. We define a new sibling fund as a fund that is initiated under the same manager of the closed fund during the closing period, and thus funds with the sole manager code of "Management Team" are excluded. ${ }^{9}$ If a fund manager closed a fund and did not start a new fund before reopening, the closing event is classified as "Close without new funds;” if a fund manager initiated new funds, the closing event is further classified into two groups based on the new fund's investment objective. About $50 \%$ of closed funds in the sample period have new sibling funds launched after the closure. A substantial proportion (70 out of 113 events) of such closed funds have new sibling funds launched in the same investment objective. If the reason behind a fund closure is that continued large inflows of cash into a fund could eventually impair the fund's ability to maintain performance integrity, then starting a new fund with the same investment objective raises questions about the closure's true motivation. We define a cloned fund as a new sibling fund that is initiated under the same manager of the closed fund during the closing period in the same investment objective.

address why some mutual funds shut out new investors but subsequently launch new funds with same fund managers and investment objectives, we do not differentiate hard closings from soft closings. Both close to new investors.

${ }^{9}$ In the Morningstar data, there are 1,690 mutual funds which have "Management Team" as their manager code during the sample period and four of them are closed funds. Even though these closed funds are included for an analysis whenever sibling funds are not involved in the analysis, the results in terms of sign and significance are still the same. 
Panel B of Table 1 reports the distribution of the sample by the frequency of fund closings. The panel shows that 94 (50\%) of the funds in the sample closed once and subsequently reopened once during our sample period. In addition, 62 sample funds closed once and did not reopen before the end of our sample period; the remaining 32 funds closed more than once during the sample period, with two funds closing and reopening three times over the sample period. Panel C reports the distribution of the length of time in months between closing and reopening events This excludes funds that remain closed till the end of sample period. For the closed funds that were reopened, the median time the funds stay closed is 20 months. The maximum (minimum) length is 116 (1) months between closing and reopening. An interesting observation emerges from this panel: closed funds for which no new sibling fund is launched tend to reopen sooner, relative to closed funds for which a new sibling is launched. Thus, while managers of closed funds may want to demonstrate integrity to existing shareholders by the closure, they are less motivated to reopen the closed funds if a new sibling fund is launched to earn greater fees. Panel D reports the distribution of the length of time in months between a fund closing and the fund family launching a new fund for the closed fund before its reopening. Half of closed funds clone new funds in less than a year after the closure. The time is much shorter than the time that closed funds reopen. It seems that closed fund managers know how to take advantage of the momentum in gaining public attention due to closing. Panel E of Table 1 reports the distribution of sample funds by fund objective, as classified by Morningstar. Not surprisingly, $58 \%$ of closed funds are classified as Small-Cap funds while $46 \%$ of closed funds are classified as Growth funds. This is consistent with the findings in Chen al. (2004), which show that the negative relation between fund size and performance is pronounced among small growth-oriented funds. 


\subsection{Characteristics comparison}

Table 2 reports the mean and median characteristics for both closed funds and other nonclosed funds in the same investment objective in the months of fund closure. By restricting our analysis to within-objective comparisons, we can identify differences in fund characteristics without the potential influence of the different fund investment styles. We report statistics on fund age, number of fund managers, manager tenure, expense ratios, $12 \mathrm{~b}-1$ fees, lagged total net assets (TNA), the fund family’s TNA, and lagged fund flows. ${ }^{10}$

Overall, closed funds are significantly larger and exhibit higher fund flow over the past 6 months than equity funds that stay open in the same investment objective. This is consistent with many closed funds citing their increasing size as the main reason they close to investors, especially after receiving excess cash flow due to large appreciation in underlying assets' value. These findings are persistent for closed funds with and without new siblings. Further, managers of closed funds for which no sibling fund is launched have relatively longer tenures than those of closed funds for which a sibling is launched. Such managers are more likely to know how to scale the funds.

Note that closed funds for which a sibling fund is launched in the same investment objective tend to be younger but may not be larger. The median TNA lagged one month in these closed funds is almost as large as in equity funds that stay open in the same investment objective. Although managers in both closed funds and non-closed funds have similar experience in terms of manager tenure, closed funds for which a sibling fund is cloned tend to have more managers in place. Stein (2002) argues that because of diseconomies of scale in processing soft

\footnotetext{
${ }^{10}$ Fund family identification codes are not available in Morningstar data. We use both Perl programming language and hand checking to verify if fund firms with the similar names belong to the same fund family. For example, both Fidelity Group and Fidelity Advisor belong to the same fund family. Both Dreyfus and Dreyfus Premier belong to the same family while Dreyfus Founders is not. We aggregate all funds' TNA as the fund family's TNA.
} 
information, multiple managers may have to fight for their investment ideas to be implemented. Thus, funds with more managers have more incentives to have new sibling funds.

Closed funds for which a sibling fund is cloned on average have lower expense ratios and a smaller marketing and distribution budget (12b-1 fee) than equity funds that stay open in the same investment objective. While it is extremely difficult to get an approval from existing shareholders to raise expense ratios, it could be easier to charge higher fees to a new fund cloned by the closed fund. ${ }^{11}$ Further, shutting out new investors can be an important way to substitute for marketing as closed funds stand out from the crowd in a competitive market. Thus, the closing and cloning strategy could be a clever way to raise management fees. We examine this issue in a great detail in Section 4.

\section{Performance over post-closure periods}

Table 3 reports monthly average abnormal returns and post-close standardized total net asset value (TNA) around closing events. The abnormal return is defined as the difference between the closed fund's returns and the benchmark returns. At the beginning of each closing event month, we identify all domestic equity funds that are in the same investment objective as the closing fund. Since a fund's total asset size is an important determinant of the fund closure decision, we independently rank funds into quintiles by size (total net asset value) and identify all funds that are in the same size quintile as the closing fund. When a fund doesn't report total net asset value (TNA) at the time of ranking, we use its TNA within the prior 6 months in the ranking. Using funds that are in the same investment objective and in the same size quintile, we calculate the equally-weighted average return as the benchmark return. The standardized TNA is

\footnotetext{
${ }^{11}$ When TIAA-CREF planned to increase expense ratios in the new management agreement for their several funds in August 2005, the increase was rejected by shareholders initially, although it was later approved.
} 
defined as the TNA at the end of each event month divided by the TNA in the closing month. We calculate each closing fund's standardized TNA first and report the mean statistics and the fraction of closed funds whose standardized TNAs are greater than one.

Mutual funds generally close after the inflow of dollars increases dramatically, which often occurs right after a period of huge returns. Indeed, Table 3 shows that all closed funds generate strong size- and objective-adjusted returns over the one year period prior to the closing. Consistent with the findings by Bris et al. (2007), we find that on average closed funds do not generate significant size- and objective-adjusted returns after the closure. However, those closed funds for which no new fund is subsequently launched do deliver positive and significant sizeand objective-adjusted returns up to 6 months after the closure shown in Panel A. ${ }^{12}$ In addition, Panel B shows that only these closed funds can sustain the growth of total net assets through good fund performance and possible cash inflow from existing shareholders. Noticeably, these managers have longer tenures in the funds (as shown in Table 2), and are likely to be more experienced. Given that most previous works on the relationship between fund scale and performance are limited to cross-sectional analyses, we provide an important piece of evidence to the literature that fund performance is scalable at least over a short time horizon.

For robustness check, we extend our analysis to a longer horizon that includes all fundmonths after closure but before the closed fund's re-open or till the end of sample period in Table 4. We calculate the average post-closure performance in two methods by either pooling returns for all fund-months, or by averaging abnormal returns across months for a closed fund first and then calculating the mean across all closed funds. We report the post-closure performance for two periods, one when closed funds without a new sibling fund and one when

\footnotetext{
${ }^{12}$ When calculating the monthly average abnormal return, we only use closed funds' returns up to the month before they re-open in the post-close period. Alternatively, we calculate cumulative abnormal holding-period returns and obtain the similar result which is available upon the request.
} 
closed funds with a new sibling fund. For the former one, we include all months of a closed fund until the launching of the first new sibling fund, its re-opening, or the end of sample period. For the latter one, we include all months of a closed fund after the first new sibling fund is launched until the closed fund reopens or the end of the sample period is reached. ${ }^{13}$ Additionally, we compare the post-launch performance to the pre-launch performance for these closed funds with sibling funds. The results in both panels clearly show that only closed funds without sibling funds are able to deliver significantly positive size- and objective-adjusted returns. Closed funds with sibling funds can neither deliver above-average returns nor maintain their pre-launching performance after sibling funds are launched.

In short, consistent with Chen et al. (2004) which show that scale need not be bad for performance depending on how the fund is organized, we find that under certain circumstances the adverse scale effect on performance can be mitigated by closing funds to investors. In contrast to closed funds without siblings, for closed funds having sibling funds launched the adverse scale effect on performance cannot be controlled by the fund closing its doors to investors. Therefore a desire to reach the fund's optimal scale is not likely to be the unique explanation for the closing decision.

One common explanation is that fund managers may close a fund after a period of huge returns because they cannot find attractive investment opportunities in the existing strategy. This interpretation can be verified by comparing risk exposure changes before and after a fund

\footnotetext{
${ }^{13}$ During a fund's closure, it is likely that more than one new fund is launched for the closed fund. To have a cleaner test, we anchor the analysis at the time when the first new sibling fund is launched. For robustness check, however, we also conduct an analysis by treating each new sibling fund launch as an independent event. For example, two new funds are launched on July 31 and September 30 for a closed fund. All of the fund-month returns after these two dates are included in post-launch performance for this closed fund while all of the fund-month returns before these two dates are included in the post-closure performance for the period when closed funds without a new sibling fund. The results, not reported for brevity, are similar to those in Table 4 but are more significant.
} 
closure. ${ }^{14}$ In the results not reported here, we find closed fund managers not only implement no different strategy before and after closure, but also adopt a similar strategy in their cloned funds over a year after their new launch. This finding casts doubt on the conjecture that a change in investment strategies explains a fund's decision to do the closing and cloning. We explore other possible explanations in the next section.

\section{Non-performance-based cconsiderations}

\subsection{Management fees and fund flows}

Given the fact that, overall, closed funds do not generate positive size- and objectiveadjusted returns after the closure and a nontrivial proportion of them have a new sibling fund launched, the suggestion that closed fund managers are acting in the best interest of shareholders is dubious. In other words, the desire to achieve optimal scale may not be the unique explanation for why funds close to new investors. Recall that Table 2 shows the fund advisor companies of closed funds that clone new sibling funds are much smaller in terms of the median firm TNA. In addition, these closed funds charge lower expense ratios and 12b-1 fees than equity funds that stay open in the same investment objective. We argue that such funds' aggregate marketing and distribution budget is smaller and hence that they have an incentive to use other means to stand out from the crowd, with fund closures being one of them.

Using the management fee data from N-SAR reports, Warner and Wu (2011) document that fund managers typically increase their fees after periods of high asset growth and superior performance. However, raising fees may not be easy for every single fund. Section 15 (a) of the

\footnotetext{
${ }^{14}$ Specifically, we regress an individual closed fund's monthly returns on the Fama and French (1996) three factors plus a momentum factor over the one year before and one year after the closure and test if the differences in factor loadings before and after the closure for closed funds are significant. Additionally, for each closed fund and the corresponding cloned funds, we run the four-factor regression using the monthly returns over the one year following the inception month of the cloned fund and test if the differences in factor loadings between the closed fund and its clones are significant. The results are available upon the request.
} 
Investment Company Act 1940 requires shareholder approval by majority votes on a contract with new raised fees. ${ }^{15}$ When it is difficult for some fund managers to obtain an approval from existing shareholders to raise fees to the desired level, it could be easier to charge higher fees to a new sibling fund launched for the closed fund managers. Closed funds in our sample on average have superior performance and high asset growth before the closing. We conjecture that managers of these closed funds have some difficulties raising fees, therefore closing and cloning strategy is the next best alternative. We provide evidence in Table 5 and Table 6.

Table 5 presents expense ratios of closed funds two years before and after the closure. Both Deli (2002) and Warner and Wu (2011) document that some equity funds charge management fees which are fixed up to a given level ("breakpoint”), with net assets above that level receiving lower marginal rates. ${ }^{16}$ To get rid of the potential confounding factor that the mutual fund fee structure and types of management organization (single management versus comanagement) might differ across different fund size and investment objectives, we adjust each variable of interest by subtracting its corresponding median. ${ }^{17}$ In each event month, we identify all funds that are both in the same investment objective and the same total net asset size quintile as the closed fund. Using these peer funds, we calculate the median-adjusted expense ratio for the closed fund by subtracting the median expense ratio of the peers from that of the closed fund.

\footnotetext{
${ }^{15}$ Under the 1940 Act, the vote of a "majority of the outstanding voting securities" means the affirmative vote of the lesser of (a) $67 \%$ or more of the voting securities present at a shareholder meeting if the holders of more than $50 \%$ of the outstanding voting securities are present or represented by proxy, or (b) more than $50 \%$ of the outstanding voting securities. Christoffersen (2001) also argues that changing the manager's contractual fee is very difficult. Given no pre-existing fee for a comparison, an advisor is arguably easier to set-up an initial fee level in a new fund.

${ }^{16}$ Multiple break points and marginal rates also exist. For example, the advisory fee in the 1999 contract for Williamsburg Investment Trust Contrarian Equity Fund is $0.75 \%$ of the first $\$ 250$ million of assets, $0.65 \%$ of the next $\$ 250$ million, and $0.50 \%$ of assets over $\$ 500$ million.

${ }^{17}$ Without the median adjustment, the variables of interest are noisier statistically. Additionally, many statistics in difference are significant in the mean but not in the median between closed funds and other equity funds remaining open in Table 2. Our median adjustment will safely guard against optimistic results.
} 
Two interesting results stand out. First, only closed funds for which a new fund is cloned on average charge expense ratios 9 to 13 basis points significantly lower than the median of their peers up to two years before the closure. Second, these closed funds still have difficulties to raise their expense ratios up to the median level two years after the closure. Both facts highlight the potential motivation behind the decision that closed funds might clone a new sibling fund in order to charge higher fees to the new fund. This argument does not apply to closed funds for which a new sibling fund is launched in different investment objectives. These closed funds neither charge lower expense ratios prior to closure nor have difficulty to keep their expense ratios above the median of their peers' after the closure. Thus, raising management fees is not the primary consideration of these closed funds for which a new sibling fund is launched in different objectives. We further analyze what factors drive funds to close and launch a new sibling fund in the same objective versus in different objective in Section 5.

Table 6 compares closed funds to new sibling funds launched for the same managers. In each new fund's inception month, we identify all funds that are both in the same investment objective and the same total net asset size quintile as the new or the closed fund. Using these funds, we calculate the median expense ratio, the median $12 \mathrm{~b}-1$ fee and the median number of managers respectively for the new and the closed fund. Although the closed funds on average charge an expense ratio 7 basis points lower than the median of their peers, they can significantly raise the median-adjusted expense ratio by 11 basis points in their cloned funds shown in Panel A. Their cloned funds charge expense ratios 4 basis points higher than the median of their peers, while new sibling funds launched for closed funds in different investment objective on average charge an expense ratio 11 basis points higher than the median of their peers shown in Panel B. A similar pattern appears in 12b-1 fees. Consistent with Table 2, these closed funds are 
commonly co-managed by about one additional manager relative to their peers. Stein (2002) argues that multiple managers may have to fight for their investment ideas to be implemented because of diseconomies of scale in processing soft information. Thus, closed funds with multiple managers tend to shut out new investors and the fund family tends to launch new sibling funds with fewer managers in charge for them.

Presumably, fund companies want to use the closure decision to demonstrate their integrity or responsibility so as to gain not only the appreciation of fund shareholders, but also the trust of potential investors. We expect that fund companies that close some of their funds receive greater public attention and thus can potentially attract more fund flows and charge higher fees when they launch new sibling funds. Above we show that the fund companies of closed funds charge higher fees in their cloned funds. The next question to address is whether the closing policy is an effective non-performance-based mechanism to attract more fund flows to the new sibling funds.

We examine this question in Table 7. We first compare the cumulative fund flows of each new sibling funds to the median fund flows of other new funds over a 6-month window starting from the beginning of either the $1^{\text {st }}$ or the $3^{\text {rd }}$ month following the inception date of the new sibling funds, and then report the average. A skip of a fund's total net asset data in two months right after the fund inception typically minimizes noises in the fund flow calculation. For each new sibling funds, we define other new funds as the funds established within the 3 months prior to the inception date of the new sibling fund in the same investment objective. Investors might chase hot assets with a certain investment style. By restricting our analysis to a within-investment objective comparison, we can extract the difference in fund flows due to the closure policy without the confounding influence of different fund investment styles. Panel A of 
Table 7 shows that only new funds launched for closed funds in different objectives are able to attract significant higher fund flows than other new funds in either 6-month windows. These new sibling funds attract at least $21.59 \%$ of cumulative fund flows more than what their peers do in a 6-month window after inception. New fund flows to the cloned funds are more sensitive to the estimation window. New sibling funds with the same objectives as their corresponding closed funds attract significant cumulative fund flows in the first 6 months after inception but not in the window of Month +3 to Month +8 .

Potential investors might arguably be more likely to believe that the closure is in the best interests of investors if the closing decision is made by those closed funds with higher abnormal pre-closure returns. Therefore, the closure policy might be more effective in attracting fund flows into new sibling funds launched for a better-performing closed fund. We explore this issue by splitting cloned funds by their corresponding closed funds' 12-month returns prior to the closure and compare the 6-month fund flows in the cloned funds to the median fund flows of other new funds. Panel A of Table 7 confirms that fund closure is indeed more effective in attracting increased cash flows into new siblings launched for the better-performing closed funds, that is, the funds in the top $30 \%$ of pre-closure abnormal returns. Relative to other new funds, new funds cloned by these reputable closed funds on average attract at least an additional 20.53\% net fund flows. The fund flow difference in new funds cloned by better-performing and poor-performing closed funds is strongly significant. The difference is not significant when new sibling funds are in different investment objectives.

One may argue that the differences in fund flows could be driven by newly cloned funds' own performance. To check this possibility, we compare each cloned funds to all other new funds in the same investment objective and same asset size quintile and report the average return 
differences. The result shows that new investors are neither better nor worse off in investing in the cloned funds in terms of insignificant abnormal returns within 6 months following the inception date of the clones. The closed fund managers just extract all the rents by raising fees in their cloned funds. In Panel B, we regress new sibling funds' 6-month cumulative medianadjusted flows from month +3 to month +8 after fund inception on new sibling funds' own characteristics: total fund asset value (TNA), expense ratio, the $1^{\text {st }}$ two-month abnormal returns, and their associated closed funds' 12-month pre-closure abnormal return ranks. Regressions are performed for two groups: new sibling funds are in the same or different objective as the closed fund. Again, we confirm that new siblings cloned by the better-performing closed funds are able to attract significant higher fund flows in the window of Month +3 to Month +8 . This implies that the fund flow differences are not driven by new fund performance, but rather the corresponding closed fund performance. Fund managers, but not investors, benefit from the superior fund flow to the new sibling funds.

\subsection{Family spillover effects}

Nanda, Wang, and Zheng (2004) show that star performance results in greater cash inflow to the fund and to other funds in its family. Zhao (2004) argue that spillover effects may provide strong incentives for fund families to close a star fund to signal and broadcast its superior performance. Given the fact that a closed fund typically has superior past performance and is the star in the family already, it is questionable why the fund family has to close the star fund to promote the spillover. Regardless of the doubt, we empirically examine whether stemming inflows into the closed fund helps to attract flows to other less stellar funds in the same fund family in Table 8. We identify other non-closed funds in the same family as the 
existing equity funds that have the same management company name, and the same fund objective code as the closing fund. ${ }^{18}$ Our sample includes 38 fund families which have both closed funds (73 in total) and corresponding non-closed funds (182 in totals) with fund flow data. We then compare the cumulative fund flows to these non-closed funds 6-months prior to the closing event month (i.e. from month -6 to month -1) and 6-months after the closing event month (i.e. from month +1 to month +6 ).

Overall, on average, 6-month cumulative flows to other funds in the same family following the closure are 5.37\% lower than the 6-month cumulative flows before closing. While closing helps to stem inflows for the new sibling funds it launched, it does not succeed in diverting investor attention to other similar funds in the same fund family. This is particularly true in the case where a new sibling fund is cloned for the closed fund in the same objective. It seems that cloned funds indeed suck out a lot fund flows without attracting new money to other funds in the same objective in the same fund family. The result is consistent with Bris et al. (2007) that monthly flows to other funds in the same fund family are $0.67 \%$ in the year after closing, significantly lower than $1.13 \%$ in the year before closing. ${ }^{19}$ Importantly, according to industry anecdotes, fund managers typically initialize the request for fund closing without substantial coordination with other managers in the fund family. Thus, it seems reasonable to

\footnotetext{
${ }^{18}$ The snapshot distribution of numbers of funds at the end of 2004 shows that more than $50 \%$ of fund families have only one fund available in each investment objective. Only 25\% of fund families have 2 or 3 funds available in large-cap objectives but 1 or 2 funds available in small-cap objectives. The pattern is similar in the snapshot distribution of numbers of funds in Year 2000.

19 The result seems contrary to Zhao (2004) that inflows to the family are significantly larger in the quarter immediately after closing. Numerous studies (for example, Gruber (1996), Chevalier and Ellison (1997), and Sirri and Tufano (1998)) have documented that mutual funds with the best recent performance experience the lion's share of new inflows. Therefore, if the family prior quarter performance is included in Zhao's panel regression, it is unknown whether the spillover effect will still exist. Another source for the contradictory result is the sample difference. While we only analyze domestic equity funds, Zhao's sample includes equity funds, sector funds, bond funds, and international funds.
} 
conclude that flow-spillover effect on other family member funds will not be primary concerns for funds making closure decisions. Our empirical results are consistent with this conclusion.

\subsection{Other considerations}

One might argue that the decision to clone is contingent on a fund performance. If a closed fund does well, it may continue to attract inflows from existing investors, and there may not be any need to have a clone. Otherwise, maybe it is time to launch a clone. Thus, the lack of excess performance, rather than the incentive for higher fees as we conjectured earlier, cause the cloning. We check this argument by comparing performance of have-cloned closed funds versus not-clone-yet closed funds up to two years after the closure but before the cloning. We actually find that have-cloned closed funds have significantly higher benchmark-adjusted returns, relative to not-clone-yet closed funds, within 6 month after the closure. The difference is not significant anymore in other time intervals. In short, the conjecture that the lack of excess performance causes the cloning is not supported by the data. The result is not reported but available upon request. In Section 5, we will continuously address the issue of cloning by taking closed fund performance after closing before new launching into consideration in a panel regression.

Given the fact that closed funds typically have more mangers in place, another alternative explanation for the closing and cloning might be that young ambitious managers of a closed fund would likely have a clone, while older managers stay with the existing closed funds. We check the managers' experience between managers of closed funds who join new sibling funds, and other managers of the same closed funds who stay. The manager's experience is defined as months worked as a fund manager in the mutual fund industry. We find that managers of closed funds for which a new fund is launched in different objectives are actually more experienced. 
Managers of closed funds who clone new funds are statistically as experienced as other managers staying in the same closed funds. In short, the conjecture that the mix of experience in fund managers causes the closing and cloning is not supported by the data. ${ }^{20}$

\section{Multivariate Analyses}

The fund closing-and-cloning phenomenon deserves further scrutiny because of potential conflicts of interest between fund shareholders and fund managers. Above, we identify several variables that individually explain why funds clone new sibling funds while closing to new investors. These variables are not mutually exclusive and some might be more important than others. Furthermore, the closed fund family ultimately makes the decision to launch a new sibling fund for the closed fund and thus some factors at the fund family level might be an important consideration for the launching decision. Also, these variables might have different explanatory powers under different market conditions (i.e., bull versus bear markets) and in different sectors (hot versus cold). Accordingly, we examine these variables simultaneously in a panel data structure in logistic regressions in Table 9. At the beginning of each calendar quarter starting from 1995, we collect data on the closed funds' fund level data, their fund family level data, and market condition data. To mainly address the issue of cloning, we include all closed funds from the quarter they are fully closed till the quarter before they reopen. For example, a mutual fund closes in May and reopens in November in the same year will be included in the $3^{\text {rd }}$ quarter of that year only in the panel data. This ensures that we can assess all possible postclosing and pre-launching information systematically.

\footnotetext{
${ }^{20}$ The median experience of managers of closed funds who clone new funds is about 72 months while it is about 73 months for other managers of the same closed funds. The median experience of managers of closed funds who launch new funds in different objectives is about 86 months while it is about 63 months for other managers of the same closed funds. The result is not reported but available upon request.
} 
Fund level data includes: prior-quarter-end fund size, prior-quarter fund flows, fund age, fund expense ratios, number of managers, average manager tenure, prior-quarter cumulative abnormal returns, and the standard deviation of prior-quarter monthly abnormal returns. Fund family level data includes prior-quarter-end family size, number of objectives in the family, number of non-closed funds in the same objective as the closed funds in the same family normalized by the average number of funds per investment objective in the fund family, and the prior-quarter asset-weighted non-closed funds' abnormal return in the family. To correctly describe the characteristics in the rest of the fund family and to perform a clearer test of the importance of family-level factors, for each closed fund in each quarter, we exclude values of the specific closed fund under consideration when we calculate family-level variables. Abnormal returns are size- and objective-adjusted as defined in Table 3. Market condition data includes the prior-quarter cumulative market excess return (Rm-Rf) and its standard deviation as well as the prior-quarter cumulative objective abnormal return (defined as the average investment objective returns minus the market returns) and its standard deviation. We use the value-weighted returns of all CRSP stocks to proxy for the market returns (Rm). Calendar year fixed effect is included in all regressions to control a potential cluster effect that funds might herd in closing and/or cloning decisions in certain years. Fund family fixed effect is also included. In Panel A, the dependent variable takes the value one if a closed fund remains closed and the manger(s) have a sibling fund in a quarter or zero if a closed fund remains closed and a sibling fund has not been launched in a quarter. In Panel B, a multinomial logistic regression is performed. The dependent variable in a given quarter is a set of three choices: a closed fund not having a new sibling fund, a closed fund having a new fund in different objective, and a closed fund having a new fund in the same objective. 
Parts of the results in Table 9 echo what we find in the univariate analysis in the previous sections. The number of managers of a fund has a positive and significant effect on the decisions to launch new siblings. Stein (2002) argues that because of diseconomies of scale in processing soft information, funds with multiple managers are less likely to grow larger as they are reluctant to accept new investors. Thus, managers of these closed funds tend to have new sibling funds launched. The evidence in Panel A supports this argument. Given one additional manager in charge of a closed fund, the chance of launching siblings is 1.11 times the chance of not launching siblings (odds ratio: 1.11). In addition, we argue that closed funds currently charging low fees also have more incentives to use closing and cloning to raise management fees in a cloned fund. Panel A confirms this argument, showing that a one-percentage increase in the expense ratio discourages launching a new fund significantly, with the chance of launching only 0.56 times the chance of not launching. Furthermore, both closed funds experiencing a worse fund flow and smaller closed funds tend to have a new sibling fund launched. A one-percentage increase in the fund flow last quarter makes a closed fund less likely to have a new fund launched in the current quarter, with the chance of launching only 0.09 times the chance of not launching. Although closed funds with higher abnormal returns after closing tend not to have a new fund launched, such a tendency is insignificant.

In consideration of fund family aspects, we uncover some insights how a fund family characteristic might affect the launch decision of new sibling funds. Possibly being more capable and aiming at achieving an investment scope, a closed fund family with a larger asset size and a fewer number of investment objectives available is more likely to launch a new sibling fund for the closed fund. Note that to extract the independent importance of family-level factors, we have excluded values of the specific fund under consideration from the construction of the 
family-level variables. Possibly due to the concern of internal competition, a closed fund family is less likely to launch a new fund if the family has more number of non-closed funds in the same objective as the closed fund normalized by the average number of funds per objective.

In a multinomial logistic regression in Panel $\mathrm{B}$, we simultaneously examine three decisions faced by a closed fund: not launching a new fund, launching a new fund in different objectives, and cloning a new fund. First, we find that rather than not having a new sibling fund, closed funds managing fewer dollar assets, facing deteriorating fund flow, and charging low expense ratio tend to have a new sibling fund launched in either a different investment objective or the same objective. Closed funds which are in a younger age or have more experienced managers tend to have a new sibling fund launched in the same investment objective rather than not to have a new fund. Second, we find that characteristics of a close fund family continuously affect the launch decision of new sibling funds. Rather than not launching a new fund, a closed fund family with a larger asset size is more likely to launch a new sibling fund for the closed fund in the same objective. When a closed fund family has more number of non-closed funds in the same objective as the closed fund normalized by the average number of funds per objective, the family is less likely launch a new fund in either a different investment objective or the same objective. For robustness check, we measure all performances based on the prior twoquarter abnormal returns and re-run the logistic regressions. The results are similar in terms of the coefficient signs and significances and not reported for the brevity consideration.

\section{Conclusions}

A fund closure is often a tip-off that a fund has reached a size such that its manager is having difficulty taking attractive positions that are large enough to improve performance. 
Consistent with the literature, this study documents that on average overall closed funds generate strong size- and objective-adjusted returns and exhibit higher fund flows over the pre-closure period. To avoid diseconomies of scale and to maintain responsiveness to changing market conditions, a fund's decision to close to new investors could therefore be consistent with serving the long-term interests of shareholders. However, only those closed funds for which no new fund is subsequently launched continuously deliver significantly positive size- and objectiveadjusted returns following the closure. In addition, these closed funds sustain the growth of total net assets through good fund performance and possible cash inflows from existing shareholders. This is an important piece of new evidence to the literature that fund performance is scalable at least over a short time interval. Closed funds for which a sibling fund is cloned cannot beat the benchmark and do not persistently maintain the growth of their total net assets after the closure. Given a nontrivial proportion of closed funds have new funds launched subsequently in the same investment objective, the scale motive for closure cannot be the sole explanation for the closure decision.

In a competitive market for mutual fund business, we argue that shutting a fund to new investors could be a non-performance-based mechanism to make the closed funds stand out from the crowd. Mutual funds' closure decision can signal good governance, enhancing the fund's reputation to both fund shareholders and potential investors. The intention here may not necessarily be to act in the best interest of existing fund shareholders, but rather to attract future business, as funds receive greater public attention when they close and have new sibling funds launched. Further, we find closed funds for which a new fund is cloned experience lower median-adjusted expense ratios before closure and have difficulties to raise the median-adjusted expense ratio after closure. Instead, by cloning popular funds, a fund is more likely to be able to 
charge higher fees. We show that, indeed, closed funds are able to raise the median-adjusted expense ratio by 11 basis points in their cloned funds, and these fund managers not only implement no different strategy before and after closure, but also adopt a similar strategy in their cloned funds over a year after their new launch.

Additionally, the closed fund managers extract all the rents by raising fees in their cloned funds and leave nothing on the table to new investors investing in the cloned funds. Overall, better-performing closed funds realize increased fund flows into new sibling funds, making the closure policy an effective non-performance-based mechanism to attract more fund flows. However, such a new fund flow attraction does not spill over to other existing non-closed funds with the same investment objective in the same fund family. In logistic regression analyses, we find that closing and cloning is an attractive marketing strategy to funds that seek to increase management fees, and funds with more managers in place. Further, smaller closed funds and closed funds experiencing deteriorating fund flows tend to have a new sibling fund launched. In examining fund family aspects, we are able to uncover some insights about the launch decision of new sibling funds by the closed fund family. Perhaps being more capable and aiming at achieving an investment scope, a closed fund family with a larger asset size and a fewer number of investment objectives available is more likely to launch a new sibling fund for the closed fund. Because of the internal competition concern, a closed fund family is less likely to launch a new fund if the family has more number of non-closed funds in the same objective as the closed fund normalized by the average number of funds per objective.

This study provides evidence that the closing-and-cloning strategy can be attractive and effective for individual mutual funds. Mutual fund advisor companies might strategically promote a closed fund manager by launching a new sibling fund for the manager and thus it 
becomes an internal reward mechanism. Nohel, Wang, and Zheng (2010) document that the arrangement of side-by-side management in mutual funds is awarded to skilled managers for the purpose of retention. Can the closing-and-cloning strategy be an effective tool for a fund family to retain a talented fund manager? We leave this question for future study.

\section{Acknowledgments}

We are grateful for valuable comments provided by Louis K.C. Chan, Bob Chirinko, Enrichetta Ravina, Rudi Schadt, Laura Starks, Russ Wermers, and participants of the 2007 European Finance Association Meetings and of seminars at the University of Illinois at Chicago. We especially thank the editor and an anonymous referee for their constructive and insightful comments that help to improve this paper. 


\section{References}

Berk, J., Green R., 2004. Mutual fund flows and performance in rational markets. Journal of Political Economy 112, 1269-1295.

Bris, A., Gulen, H., Kadiyala, P., Rau, R., 2007. Good stewards, cheap talkers, or family men? The impact of mutual fund closures on fund managers, flows, fees, and performance. Review of Financial Studies 20, 953-982.

Brush, T., Karnani, A., 1996. Impact of plant size and focus on productivity: An empirical study. Management Science 42, 1065-1081.

Chen, J., Hong, H., Huang, M., Kubik, J., 2004. Does fund size erode mutual fund performance? The role of liquidity and organization. American Economic Review 95, 1276-1302.

Chevalier, J., Ellison, G., 1997. Risk taking by mutual funds as a response to incentives. Journal of Political Economy 105, 1167-1200.

Christensen, L., Greene, W., 1976. Economies of scale in U.S. electric power generation. Journal of Political Economy 84, 655-676.

Christoffersen, S., 2001. Why do money fund managers voluntarily waive their fees? Journal of Finance 56, 1117-1140

Deli, D., 2002. Mutual fund advisory contracts: An empirical investigation. Journal of Finance 57, 109-133.

Fama, E., French, K., 1996. Multifactor explanations of asset pricing anomalies. Journal of Finance $51,55-84$.

Fama, E., MacBeth, J., 1973. Risk, return and equilibrium: Empirical tests. Journal of Political Economy 81, 607-636.

Gruber, M., 1996. Another puzzle: The growth in actively managed mutual funds. Journal of Finance 51, 783-810.

Manakyan, H., Liano, K., 1997. Performance of mutual funds before and after closing to new investors. Financial Services Review 6, 257-269.

Murray, J., White, R., 1983. Economies of scale and economies of scope in multiproduct financial institutions: A study of British Columbia credit unions. Journal of Finance 38, 887-902.

Nanda, V., Wang, J., Zheng, L., 2004. Family values and the star phenomenon: Strategies of mutual fund families. Review of Financial Studies 17, 667-698. 
Nohel, T., Wang, J., Zheng, L., 2010. Side-by-side management of hedge funds and mutual funds. Review of Financial Studies 23, 2342-237.

Perold, A., Salomon, R., 1991. The right amount of assets under management. Financial Analysts Journal 47, 31-39.

Scharfstein, D., Stein, J., 1990. Herd behavior and investment. American Economic Review 80, 465-479.

Sirri, E., Tufano, P., 1998. Costly search and mutual fund flows. Journal of Finance 53, 15891622.

Smaby, T., Fizel, J., 1995. Fund closings as a signal to investors: Investment performance of open-end mutual funds that close to new shareholders. Financial Services Review 4, 71-80.

Stein, J., 2002. Information production and capital allocation: Decentralized versus hierarchical firms. Journal of Finance 57, 1891-1921.

Trostel, P., 2004. Returns to scale in producing human capital from schooling. Oxford Economic Papers 56, 461-484.

Warner, J., Wu, J., 2011. Why do mutual fund advisory contracts change? Performance, growth, and spillover effects. Journal of Finance 66, 271-306.

Zhao, X., 2004. Why are some mutual funds closed to new investors? Journal of Banking and Finance 28, 1867-1887. 


\section{Table 1 Descriptive Sample Statistics}

Panel A reports the number of closing events by year and by whether a closing event is associated with a subsequent new fund initiation under the same manager. The sample period is from 1995 to 2004. A new sibling fund is defined as a fund that is initiated during the closing period under the same manager. If a fund manager closed a fund and did not start a new sibling fund before reopening the closed fund, the closing event is classified as "Close without new sibling fund;" if a fund manager(s) initiated new sibling funds, the closing event is further classified into two groups based on the new fund(s)' investment objectives. We also report number of total domestic equity funds available for investment at the beginning of each year as a proxy for investment opportunity sets. In the last two columns, we report annual S\&P 500 index returns and Russell 2000 index returns from 1995-2004.

Panel B reports the number of times each fund closed and reopened during 1995-2004.

Panel C reports the number of months between each fund's closing and reopen events during 1995-2004. The sample size is smaller because some funds that are closed during the sample period never reopen as of December 2004.

Panel D reports the number of months between closed funds' closing months and their sibling funds' (if there is any) inception months. It includes only those closed funds that subsequently launch sibling funds.

Panel E reports the number of closing events by the fund's investment objective at the beginning of the event month. The closing events are also classified by whether a closing event is associated with the initiation of a new fund. Percentage of the closing events in the investment objective is reported in parentheses.

\section{Panel A: Number of Closing Events (1995-2004)}

\begin{tabular}{|c|c|c|c|c|c|c|c|}
\hline \multirow[t]{2}{*}{ Year } & \multirow{2}{*}{$\begin{array}{c}\text { \# of } \\
\text { Events }\end{array}$} & \multirow{2}{*}{$\begin{array}{c}\text { Close w/o } \\
\text { New Sibling } \\
\text { Funds }\end{array}$} & \multicolumn{2}{|c|}{ Close w/ New Sibling Funds } & \multirow{2}{*}{$\begin{array}{c}\text { \# of Funds } \\
\text { Available }\end{array}$} & \multirow[t]{2}{*}{ S\&P 500} & \multirow{2}{*}{$\begin{array}{c}\text { Russell } \\
2000\end{array}$} \\
\hline & & & Same Objective & Diff. Objective & & & \\
\hline 1995 & 16 & 6 & 7 & 3 & 1048 & 37.52 & 28.46 \\
\hline 1996 & 18 & 7 & 7 & 4 & 1154 & 22.92 & 16.51 \\
\hline 1997 & 11 & 5 & 4 & 2 & 1260 & 33.34 & 22.37 \\
\hline 1998 & 17 & 11 & 3 & 3 & 1422 & 28.60 & -2.56 \\
\hline 1999 & 25 & 10 & 9 & 6 & 1652 & 21.03 & 21.26 \\
\hline 2000 & 23 & 9 & 9 & 5 & 1807 & -9.09 & -3.03 \\
\hline 2001 & 20 & 8 & 6 & 6 & 1964 & -11.85 & 2.49 \\
\hline 2002 & 31 & 10 & 13 & 8 & 2135 & -22.10 & -20.48 \\
\hline 2003 & 22 & 17 & 5 & & 2234 & 28.67 & 47.25 \\
\hline 2004 & 45 & 32 & 7 & 6 & 2249 & 10.86 & 18.32 \\
\hline All & 228 & 115 & 70 & 43 & & & \\
\hline
\end{tabular}


Panel B: Number of Multiple Closings during Sample Period

\begin{tabular}{|c|c|c|c|c|c|}
\hline Close Times & Reopen Times & \# of Events & Event Description & \# of close w/o New & \# of close w/ New \\
\hline 1 & & 62 & closed once with no reopen & 26 & 36 \\
\hline 1 & 1 & 94 & closed once and reopen once & 50 & 44 \\
\hline 2 & 1 & 17 & closed twice and reopen once & 6 & 11 \\
\hline 2 & 2 & 7 & closed twice and reopen twice & 4 & 3 \\
\hline 3 & 2 & 6 & closed three times and reopen twice & 3 & 3 \\
\hline 3 & 3 & 2 & closed three times and reopen three times & 2 & 0 \\
\hline
\end{tabular}

Panel C: Months between Closing and Reopen Events

\begin{tabular}{lcccccc}
\hline & \# of Close Funds & Min & $\mathbf{2 5 \%}$ & Median & $\mathbf{7 5 \%}$ & Max \\
\hline Close All & 143 & 1 & 9 & 20 & 35 & 116 \\
Close w/o New Siblings & 78 & 1 & 6 & 12 & 24 & 82 \\
Close w/ New Siblings & & & & & & \\
Same Objective & 38 & 5 & 20 & 29.5 & 43 & 114 \\
$\quad$ Diff. Objective & 27 & 3 & 21 & 33 & 57 & 116 \\
\hline
\end{tabular}

Panel D: Months between Closing a Fund and Launching its New Sibling Funds $\begin{array}{llllll}\text { \# of New Funds } & \text { Min } & 25 \% & \text { Median } & 75 \% & \text { Max }\end{array}$

Close w/ New Siblings

\begin{tabular}{lcccccc} 
Same Objective & 84 & 0 & 6.5 & 10.5 & 23 & 90 \\
Diff. Objective & 142 & 0 & 7 & 17 & 29 & 108 \\
\hline
\end{tabular}


Table 1-Continued

Panel E: Number of Closing Events by Fund Objective

\begin{tabular}{|c|c|c|c|c|c|c|c|}
\hline & \multirow[t]{2}{*}{ \# of Events } & \multirow{2}{*}{\multicolumn{2}{|c|}{$\begin{array}{l}\text { Close w/o New } \\
\text { Sibling Funds }\end{array}$}} & \multicolumn{4}{|c|}{ Close w/ New Sibling Funds } \\
\hline & & & & \multicolumn{2}{|c|}{ Same Objective } & \multicolumn{2}{|c|}{ Diff. Objective } \\
\hline Large Blend & 24 & 9 & (38\%) & 14 & $(58 \%)$ & 1 & $(4 \%)$ \\
\hline Large Growth & 17 & 4 & $(24 \%)$ & 10 & $(59 \%)$ & 3 & $(18 \%)$ \\
\hline Large Value & 3 & 2 & $(67 \%)$ & 1 & $(33 \%)$ & & \\
\hline Mid-Cap Blend & 14 & 10 & (71\%) & 2 & $(14 \%)$ & 2 & $(14 \%)$ \\
\hline Mid-Cap Growth & 27 & 17 & $(63 \%)$ & 7 & $(26 \%)$ & 3 & $(11 \%)$ \\
\hline Mid-Cap Value & 11 & 8 & (73\%) & & & 3 & $(27 \%)$ \\
\hline Small Blend & 35 & 20 & $(57 \%)$ & 8 & $(23 \%)$ & 7 & $(20 \%)$ \\
\hline Small Growth & 62 & 29 & $(47 \%)$ & 19 & $(31 \%)$ & 14 & $(23 \%)$ \\
\hline Small Value & 35 & 16 & $(46 \%)$ & 9 & $(26 \%)$ & 10 & $(29 \%)$ \\
\hline All & 228 & 115 & $(50 \%)$ & 70 & $(31 \%)$ & 43 & $(19 \%)$ \\
\hline
\end{tabular}


Table 2 Characteristics of Closed Funds versus Non-Closed Funds

This table reports the mean and median characteristics for closed funds versus non-closed funds in the same investment objective in the month of fund closure. Fund age is the number of years from the fund inception month to the closing month. Number of fund managers is self explanatory. Manager tenure is the number of years from the manager's starting month to the fund's closing month. If a fund has multiple managers, manger tenure of that fund is the average tenure of all the managers of the fund. The expense ratio (12b- 1 fee) is the average expense ratio (12b-1 fee) of all share classes in the fund. Both the fund's total net asset (TNA) values and the fund family's TNA (Family TNA) are reported in millions of dollars. Lagged values represent the fund TNA in the month before the closure month. We calculate the fund flows using the formula provided in Sirri and Tufano (1998). We report both the onemonth lagged fund flows and the average monthly fund flows over the past 6 months before the closing month. The p-values represent the test of the hypothesis that the differences in the characteristics between closed funds and nonclosed funds are zero. Statistics are reported for the whole sample and for subsamples in which closing events are further classified as to whether a closing event is associated with the initiation of a new fund before the next reopen, if there is any.

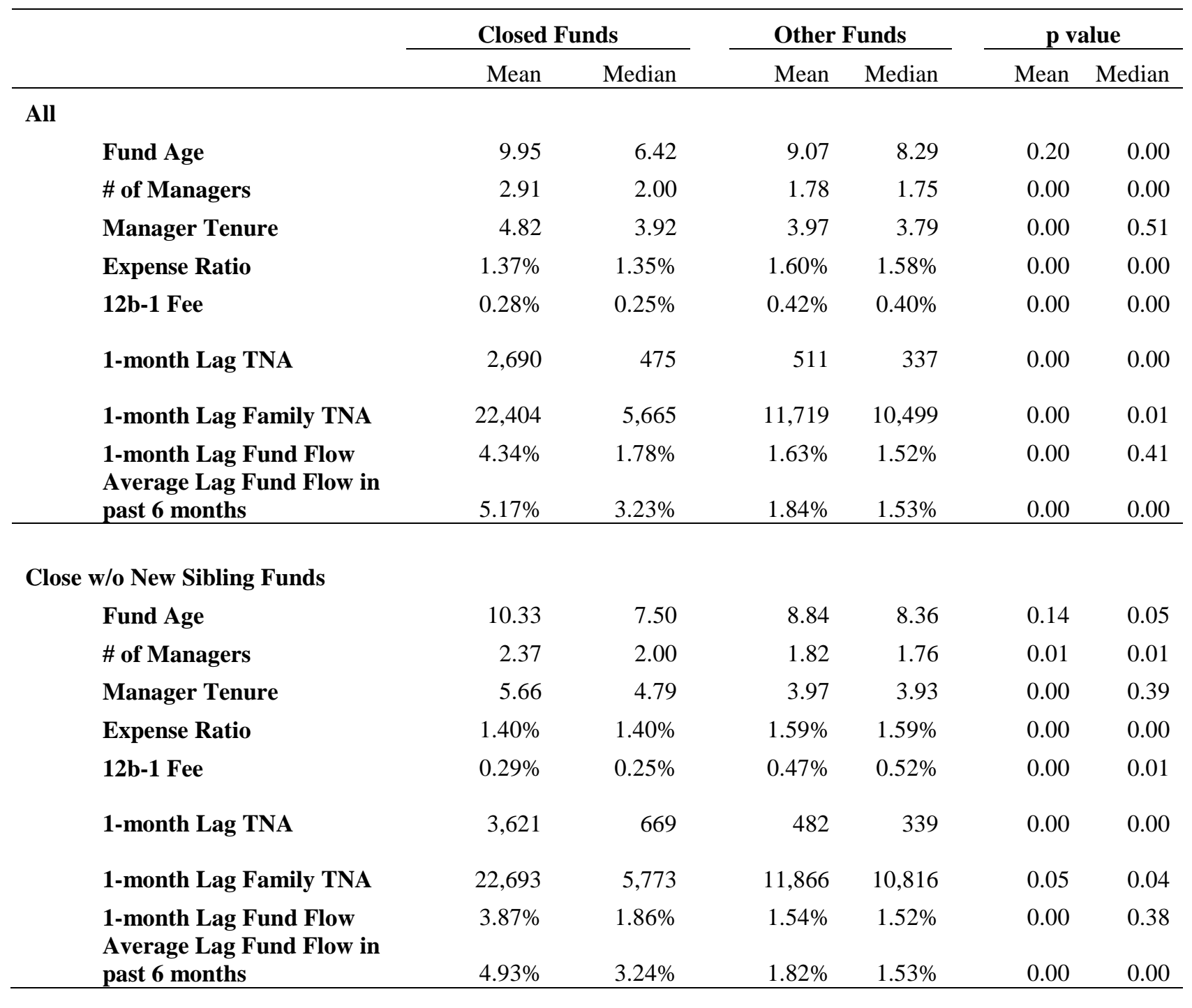


Table 2-Continued

\begin{tabular}{|c|c|c|c|c|c|c|}
\hline & \multicolumn{2}{|c|}{ Closed Funds } & \multicolumn{2}{|c|}{ Other Funds } & \multicolumn{2}{|c|}{ p value } \\
\hline & Mean & Median & Mean & Median & Mean & Median \\
\hline \multicolumn{7}{|l|}{ Close w/ New Sibling Funds } \\
\hline \multicolumn{7}{|l|}{ Same Objective } \\
\hline Fund Age & 11.56 & 6.75 & 9.78 & 9.00 & 0.21 & 0.11 \\
\hline \# of Managers & 3.51 & 3.00 & 1.76 & 1.78 & 0.00 & 0.00 \\
\hline Manager Tenure & 4.00 & 3.38 & 4.12 & 3.79 & 0.84 & 0.55 \\
\hline Expense Ratio & $1.26 \%$ & $1.21 \%$ & $1.59 \%$ & $1.53 \%$ & 0.00 & 0.00 \\
\hline 12b-1 Fee & $0.27 \%$ & $0.25 \%$ & $0.39 \%$ & $0.36 \%$ & 0.01 & 0.00 \\
\hline 1-month Lag TNA & 2,392 & 376 & 607 & 371 & 0.05 & 0.86 \\
\hline 1-month Lag Family TNA & 25,659 & 5,558 & 12,470 & 10,405 & 0.10 & 0.22 \\
\hline 1-month Lag Fund Flow & $3.69 \%$ & $1.47 \%$ & $1.77 \%$ & $1.30 \%$ & 0.04 & 0.67 \\
\hline past 6 months & $3.58 \%$ & $1.93 \%$ & $1.69 \%$ & $1.30 \%$ & 0.01 & 0.44 \\
\hline \multicolumn{7}{|l|}{ Diff. Objective } \\
\hline Fund Age & 6.32 & 4.50 & 8.53 & 7.51 & 0.03 & 0.00 \\
\hline \# of Managers & 3.33 & 3.00 & 1.72 & 1.72 & 0.00 & 0.00 \\
\hline Manager Tenure & 3.96 & 3.58 & 3.71 & 3.60 & 0.46 & 0.83 \\
\hline Expense Ratio & $1.48 \%$ & $1.29 \%$ & $1.62 \%$ & $1.59 \%$ & 0.00 & 0.02 \\
\hline 12b-1 Fee & $0.29 \%$ & $0.25 \%$ & $0.38 \%$ & $0.34 \%$ & 0.19 & 0.03 \\
\hline 1-month Lag TNA & 759 & 409 & 433 & 293 & 0.30 & 0.02 \\
\hline 1-month Lag Family TNA & 16,437 & 6,064 & 10,114 & 8,587 & 0.00 & 0.19 \\
\hline $\begin{array}{l}\text { 1-month Lag Fund Flow } \\
\text { Average Lag Fund Flow in }\end{array}$ & $6.52 \%$ & $4.02 \%$ & $1.67 \%$ & $1.75 \%$ & 0.01 & 0.16 \\
\hline past 6 months & $8.27 \%$ & $6.36 \%$ & $2.14 \%$ & $1.91 \%$ & 0.00 & 0.00 \\
\hline
\end{tabular}




\section{Table 3 Abnormal Returns and Standardized TNA around the Closing Events}

The benchmark is defined as follows. At the beginning of each closing event month, we identify all funds that are in the same investment objective as the closing fund; independently, we rank funds into quintiles by total net asset value and identify all funds that are in the same size quintile as the closing fund. Using funds that are both in the same investment objective and size quintile, we calculate the average return as the benchmark return. We report the average of monthly abnormal returns (the fund's returns minus benchmark returns over an event window), and the p-value of the hypothesis that the abnormal return is zero. Panel B presents measures of fund growth after closure. We define the standardized TNA (STNA) as the TNA at the end of the event month divided by the closing month TNA. We calculate each closing fund's STNA first and report the mean statistics with the p-value in the parenthesis to test if STNA equals to 1 . We also reports the fraction of closed funds whose STNAs are greater than 1 with the p-value in the parenthesis to test if the fraction equals to 0.5.

\section{Panel A: Abnormal Returns around Closure}

\begin{tabular}{|c|c|c|c|c|c|c|c|c|}
\hline & & & Close Pe & & & & t-Close P & \\
\hline & & $\begin{array}{l}-12 \sim-7 \\
\text { months }\end{array}$ & $\begin{array}{c}-6 \sim-4 \\
\text { months }\end{array}$ & $\begin{array}{c}-3 \sim-1 \\
\text { months }\end{array}$ & $\begin{array}{l}\text { Close- } \\
\text { month }\end{array}$ & $\begin{array}{c}1 \sim 3 \\
\text { months }\end{array}$ & $\begin{array}{c}4 \sim 6 \\
\text { months }\end{array}$ & $\begin{array}{c}7 \sim 12 \\
\text { months }\end{array}$ \\
\hline All & Mean & $0.75 \%$ & $0.65 \%$ & $0.76 \%$ & $0.17 \%$ & $0.27 \%$ & $0.22 \%$ & $-0.21 \%$ \\
\hline & p value & 0.00 & 0.00 & 0.00 & 0.49 & 0.10 & 0.10 & 0.05 \\
\hline w/o New Sibling Funds & Mean & $0.90 \%$ & $0.73 \%$ & $0.69 \%$ & $0.25 \%$ & $0.23 \%$ & $0.35 \%$ & $-0.21 \%$ \\
\hline & p value & 0.00 & 0.00 & 0.00 & 0.42 & 0.05 & 0.04 & 0.19 \\
\hline w/ New Sibling Funds & & & & & & & & \\
\hline Same Objective & Mean & $0.58 \%$ & $0.65 \%$ & $1.04 \%$ & $0.10 \%$ & $0.44 \%$ & $-0.05 \%$ & $-0.28 \%$ \\
\hline & p value & 0.01 & 0.05 & 0.00 & 0.83 & 0.24 & 0.84 & 0.13 \\
\hline Diff. Objective & Mean & $0.60 \%$ & $0.42 \%$ & $0.52 \%$ & $0.06 \%$ & $0.10 \%$ & $0.29 \%$ & $-0.14 \%$ \\
\hline & p value & 0.02 & 0.32 & 0.08 & 0.92 & 0.76 & 0.41 & 0.59 \\
\hline
\end{tabular}

Panel B: Post-Close Standardized TNA

Event Month After the Closure

\begin{tabular}{|c|c|c|c|c|c|c|}
\hline & \multirow{2}{*}{\multicolumn{3}{|c|}{ Standardized TNA }} & \multirow{2}{*}{\multicolumn{3}{|c|}{ Fraction of Closed Funds with STNA $>1$}} \\
\hline & & & & & & \\
\hline & 3-month & 6-month & 12-month & 3-month & 6-month & 12-months \\
\hline \multirow[t]{2}{*}{ All } & 1.07 & 1.11 & 1.13 & $61.29 \%$ & $60.47 \%$ & $57.55 \%$ \\
\hline & $(0.00)$ & $(0.00)$ & $(0.00)$ & $(0.00)$ & $(0.00)$ & $(0.03)$ \\
\hline \multirow[t]{2}{*}{ w/o New Sibling Funds } & 1.08 & 1.12 & 1.17 & $63.30 \%$ & $64.22 \%$ & $60.19 \%$ \\
\hline & $(0.01)$ & $(0.01)$ & $(0.01)$ & $(0.01)$ & $(0.00)$ & $(0.03)$ \\
\hline \multicolumn{7}{|l|}{ w/ New Sibling Funds } \\
\hline \multirow[t]{2}{*}{ Same Objective } & 1.07 & 1.06 & 1.07 & $54.41 \%$ & $55.00 \%$ & $51.28 \%$ \\
\hline & $(0.07)$ & $(0.02)$ & $(0.13)$ & $(0.46)$ & $(0.53)$ & $(0.87)$ \\
\hline \multirow[t]{2}{*}{ Diff. Objective } & 1.08 & 1.14 & 1.11 & $67.50 \%$ & $57.58 \%$ & $56.92 \%$ \\
\hline & $(0.14)$ & $(0.03)$ & $(0.12)$ & $(0.03)$ & $(0.22)$ & $(0.26)$ \\
\hline
\end{tabular}




\section{Table 4 Robustness Check on Post-Closure Performance}

This table presents closed funds' post-closure performance measured by size- and objective-adjusted returns defined in Table 3. Every month following a fund's closure, we calculate the closed fund' abnormal return until the closed fund's re-open or the end of sample period. We present the average performance in two methods: (1) we pool all fund-month observations in Panel A; (2) we average abnormal return across months for a closed fund first and then calculate the mean across all closed funds in Panel B. We report the post-closure performance for two periods, one when closed funds without a new sibling fund and one when closed funds with a new sibling fund. For the former one, we include all months of a closed fund until the launching of the first new sibling fund, its re-opening, or the end of sample period. For the latter one, we include all months of a closed fund after the first new sibling fund is launched until the closed fund reopens or the end of the sample period is reached. For the latter one, we additionally compare the post-launch performance to the pre-launch performance for the closed funds with sibling funds. We report the number of observations in the brackets, the average performance, the p-value, and the significance level indicated by the sup-script *** $(1 \%)$, ** (5\%), and * $(10 \%)$.

\begin{tabular}{|c|c|c|c|c|}
\hline & \multicolumn{3}{|c|}{ Post-Closure Abnormal Returns [\#obs.] } & p-value \\
\hline \multicolumn{5}{|l|}{ Panel A: Statistics with all fund-month observations } \\
\hline Months when closed funds do not have sibling funds & \multicolumn{2}{|c|}{$0.1421^{* * *}[3399]$} & & 0.00 \\
\hline Months when closed funds have sibling funds & \multicolumn{2}{|c|}{$-0.0529[2997]$} & & \multirow[t]{2}{*}{0.22} \\
\hline Further Analysis & Pre-launch & Post-launch & Difference & \\
\hline All closed-funds with Siblings & $0.1627[1233]$ & $-0.0529[2997]$ & $-0.2157^{* *}$ & 0.02 \\
\hline Close-funds with Siblings in the Same Obj. & $0.2102[678]$ & $-0.0843[1707]$ & $-0.2945^{* * *}$ & 0.00 \\
\hline Close-funds with Siblings in the Diff Obj. & $0.1047[555]$ & $-0.014[1290]$ & -0.1162 & 0.51 \\
\hline \multicolumn{5}{|c|}{ Panel B: Statistics with averaging abnormal returns across time for a closed fund first and then averaging across closed funds } \\
\hline Months when closed funds do not have sibling funds & \multicolumn{2}{|c|}{$0.1538^{*}[228]$} & & 0.08 \\
\hline Months when closed funds have sibling funds & \multicolumn{2}{|c|}{$-0.0298[103]$} & & \multirow[t]{2}{*}{0.72} \\
\hline Further Analysis & Pre-launch & Post-launch & Difference & \\
\hline All closed-funds with Siblings & $0.2182[103]$ & $-0.0289[103]$ & -0.2382 & 0.14 \\
\hline Close-funds with Siblings in the Same Obj. & $0.1393[65]$ & $0.0527[65]$ & -0.0974 & 0.56 \\
\hline Close-funds with Siblings in the Diff Obj. & $0.3449[38]$ & $-0.1704[38]$ & -0.4643 & 0.17 \\
\hline
\end{tabular}




\section{Table 5 Median-Adjusted Expense Ratios of Closed Funds}

This table reports the average median-adjusted expense ratios of closed funds up to two years before and after closing events. The median adjusted expense ratio is defined as the difference between a closed fund's expense ratio and the median expense ratios of the matched funds. We identify matched funds as follows. At the beginning of each event month, we identify all funds that are in the same investment objective as the closing fund; independently, we rank funds into quintiles by size (total net asset value) and identify all funds that are in the same size quintile as the closing fund. Matched funds are those in the same investment objective and in the same size quintile. After we calculate median-adjusted expense ratio for individual closed funds, we report the cross-sectional means of all closed funds, and of subsets in which closing events are further classified as to whether a closing event is associated with the initiation of a new fund. The difference of expense ratios is defined as post-close expense ratio minus pre-close expense ratio.

\begin{tabular}{|c|c|c|c|c|c|c|c|c|c|c|}
\hline & & \multicolumn{3}{|c|}{ Pre-Close Period } & \multicolumn{3}{|c|}{ Post-Close Period } & \multicolumn{3}{|c|}{ Difference } \\
\hline & & 24-month & 12-month & 6-month & 6-month & 12-month & 24-month & 6-month & 12-month & 24-month \\
\hline \multirow[t]{2}{*}{ All } & Mean & -0.01 & -0.01 & 0.02 & 0.02 & -0.01 & 0.01 & 0.00 & 0.00 & 0.02 \\
\hline & p value & 0.78 & 0.74 & 0.56 & 0.46 & 0.83 & 0.37 & 0.69 & 0.86 & 0.55 \\
\hline \multirow[t]{2}{*}{ w/o New Siblings } & Mean & -0.01 & 0.02 & 0.06 & 0.06 & 0.04 & 0.05 & 0.00 & 0.02 & 0.06 \\
\hline & p value & 0.87 & 0.65 & 0.22 & 0.21 & 0.48 & .92 & 0.89 & 0.60 & 0.13 \\
\hline \multicolumn{11}{|l|}{ w/ New Siblings } \\
\hline \multirow[t]{2}{*}{ Same Objective } & Mean & -0.10 & -0.13 & -0.09 & -0.06 & -0.05 & -0.02 & 0.03 & 0.08 & 0.08 \\
\hline & p value & 0.06 & 0.02 & 0.04 & 0.23 & 0.24 & 0.77 & 0.26 & 0.15 & 0.24 \\
\hline \multirow[t]{2}{*}{ Diff. Objective } & Mean & 0.13 & 0.10 & 0.09 & 0.07 & 0.05 & 0.04 & -0.02 & -0.05 & -0.09 \\
\hline & p value & 0.19 & 0.20 & 0.17 & 0.32 & 0.45 & 0.67 & 0.57 & 0.29 & 0.19 \\
\hline
\end{tabular}




\section{Table 6 Closed Funds and New Sibling Funds Comparison: Median-Adjusted Fees and Number of Managers}

This table reports median-adjusted statistics for fund expense ratios, 12b- 1 fees, and number of managers between closed funds and the corresponding new funds under the same manager. New sibling funds are defined in Table 1. The median-adjusted statistic is defined as the variable of interest minus its corresponding median. We find the median as the following. In each new fund's inception month, we identify all funds that are in the same investment objective as the new (closed) fund; separately, we also identify all funds that are in the same size quintile as the new (closed) funds; using funds that are in the same investment objective and in the same size quintile, we calculate the median expense ratio, the median 12b-1 fee and the median number of managers. After we get the median-adjusted result for each individual fund, we report the statistical means of the median-adjusted variable. Whether the average value of the variable of interest is significantly different from the median is indicated using the asterisks. Panel A gives means of median-adjusted expense ratios, $12 \mathrm{~b}-1$ fees, and the number of managers for the sub-sample of new sibling funds in the same investment objective as the corresponding closed funds. Panel B gives the median-adjusted statistics for the sub-sample of new sibling funds with a different investment objective from the corresponding closed funds. The p-value tests the hypothesis that the differences between the new funds and the closed funds are zero and the associated significance levels of 10,5 , and $1 \%$ are indicated by the asterisks *, **, and ***, respectively.

Panel A: New Sibling Funds in Same Objective

\begin{tabular}{lccccc} 
& Exp Ratio \% & & $\mathbf{1 2 b - 1}$ Fee \% & & \# of Managers \\
\cline { 2 - 2 } \cline { 5 - 5 } Closed Funds & -0.07 & & $-0.13^{* *}$ & & $0.80^{* *}$ \\
New Sibling Funds & 0.04 & & -0.07 & & 0.48 \\
Diff. (New-Closed) & $0.11^{* *}$ & & $0.06^{* *}$ & & -0.32 \\
& & & & \\
\hline
\end{tabular}

Panel B: New Sibling Funds in Different Objective

\begin{tabular}{lccccc} 
& Exp Ratio \% & & 12b-1 Fee \% & & \# of Managers \\
\cline { 2 - 2 } \cline { 5 - 6 } Closed Funds & 0.06 & & $0.23^{* * *}$ & & $0.94^{* * *}$ \\
New Sibling Funds & $0.11^{* *}$ & & $0.24^{* * *}$ & & $0.87^{* * *}$ \\
Diff. (New-Closed) & 0.05 & & 0.01 & & -0.07
\end{tabular}


Table 7 Median-Adjusted Fees/Flows and Mean Abnormal Returns of New Sibling Funds

We analyze new sibling funds' expense ratios, 6-month cumulative fund flows, and the average of cumulative abnormal returns in the first 6 months after a fund's inception. We define the 6-month cumulative flow as fund flows either from month +1 to month +6 or from month +3 to month +8 after fund inception. New sibling funds are defined in Table 1. We investigate only two groups of new sibling funds: those with the same investment objective as the corresponding closed funds, and those with the different investment objective as the corresponding closed funds. The median-adjusted statistic is defined as the variable of interest minus its corresponding median. We define the median as the following: for each new sibling fund, we identify all other new funds in the same investment objective, and with the inception dates within the prior 3 months of the new fund inception date. We find the median expense ratio, and 6-month cumulative fund flow of all other new funds. Mean abnormal return is calculated in a similar way as in Table 3, except the benchmark is composed of all other new funds in the same investment objective and same asset size quintile. In Panel A, we report statistics for all new funds, and then for two groups of new funds, depending on their corresponding closed funds' 12-month prior closure abnormal returns at the top 30\% or at the bottom $30 \%$. In Panel B, we regress new sibling funds' 6-month cumulative median-adjusted flows from month +3 to month +8 after fund inception on new sibling funds' own characteristics: total fund asset value (TNA), expense ratio, the $1^{\text {st }}$ two-month abnormal return, and their associated closed funds' 12 -month pre-closure abnormal return rank. TNA is measured at the end of the first full month after the new fund inception. The associated closed fund's performance is assigned a rank of 1 to 3 according to its 12-month pre-closure abnormal returns. Using funds that are both in the same investment objective and size quintile as the benchmark, we calculate 12-month pre-closure abnormal returns for all available funds. A rank of 1 (3) indicates that a fund's 12-month pre-closure benchmarkadjusted performance is in the bottom (Top) 30\%. Regressions are done within two separate groups: new sibling funds that have the same objective as the closed fund, and new sibling funds with different objectives from the closed fund. Coefficient estimates are reported and the significance level is indicated by the sup-script *** (1\%), ** (5\%), and * (10\%).

Panel A: Statistics on New Sibling Funds’ Fees, Flows, and Returns

\begin{tabular}{|c|c|c|c|c|c|}
\hline & & \multicolumn{4}{|c|}{ New Sibling Funds } \\
\hline & & $\begin{array}{l}\text { Exp } \\
\text { Ratio \% }\end{array}$ & $\begin{array}{c}1^{\text {st }} \text { 6-month } \\
(+1 \sim+6) \text { Cum. } \\
\text { Flow \% }\end{array}$ & $\begin{array}{c}\text { 6-month } \\
(+3 \sim+8) \\
\text { Cum. Flow \% }\end{array}$ & $\begin{array}{l}\text { First 6-month } \\
\text { Abnormal } \\
\text { Return }\end{array}$ \\
\hline \multicolumn{6}{|c|}{ Panel A1: New Sibling Funds with Same Objective as the Closed Funds } \\
\hline $\begin{array}{l}\text { All } \\
\text { The Corresponding Closed Funds }\end{array}$ & Est. & -0.02 & $16.98^{* * *}$ & 7.08 & -0.08 \\
\hline $\begin{array}{l}\text { Performance in Top } 30 \% \\
\text { The Corresponding Closed Funds }\end{array}$ & Est. & 0.14 & $29.03^{* * *}$ & $20.53^{*}$ & -0.06 \\
\hline Performance in Bottom $30 \%$ & Est. & -0.12 & $10.10^{* * *}$ & -6.91 & -0.11 \\
\hline Diff (Top 30\% - Bottom 30\%) & Est. & 0.26 & $18.94^{* * *}$ & $27.44^{* *}$ & 0.05 \\
\hline \multicolumn{6}{|c|}{ Panel A2: New Sibling Funds with Different Objective as the Closed Funds } \\
\hline $\begin{array}{l}\text { All } \\
\text { The Corresponding Closed Funds }\end{array}$ & Est. & 0.02 & $24.64^{* * *}$ & $21.59^{* * *}$ & 0.14 \\
\hline $\begin{array}{l}\text { Performance in Top } 30 \% \\
\text { The Corresponding Closed Funds }\end{array}$ & Est. & 0.25 & $32.12^{*}$ & $32.70^{*}$ & 0.42 \\
\hline Performance in Bottom 30\% & Est. & -0.24 & $28.03^{* *}$ & $27.09^{* *}$ & -0.06 \\
\hline Diff (Top 30\% - Bottom 30\%) & Est. & 0.49 & 4.10 & 5.61 & 0.48 \\
\hline
\end{tabular}


Table 7-Continued

Panel B: A Multivariate Regression (Dependent Variable: New Sibling Funds' 6-Month Cumulative Medianadjusted Fund Flows from Month +3 to Month +8 after the Fund Inception)

\begin{tabular}{lcc}
\hline & \multicolumn{2}{c}{ Coefficient Estimates } \\
\cline { 2 - 3 } Independent Variables & $\begin{array}{l}\text { New Sibling Funds with } \\
\text { Same Objective as the } \\
\text { Closed Funds }\end{array}$ & $\begin{array}{l}\text { New Sibling Funds with } \\
\text { different Objective as the } \\
\text { Closed Funds }\end{array}$ \\
\hline Intercept & -0.0517 & 0.1683 \\
Fund Size (TNA) & $-1.01 \mathrm{E}-11$ & $-3.74 \mathrm{E}-11$ \\
Expense Ratio & -0.0922 & 0.0254 \\
$\mathbf{1}^{\text {st }}$ Two-Month Abnormal Return & 0.0039 & 0.0063 \\
Close Fund Abnormal Return Rank & $0.1360^{* * *}$ & -0.0537 \\
Adjusted R & & 0.01 \\
Sample Size & 0.07 & 108 \\
\hline
\end{tabular}




\section{Table 8 Family Spillover Effects}

This table tests the fund-flow spillover effects of closed funds on the non-closed funds with the same investment objectives in the same fund family. In the closed fund closing event month, we identify all existing non-closed funds in the same objective as the closed fund in the same fund management company. We then compare the cumulative fund flows to those non-closed funds over the 6-month window prior to the closing event month (i.e. from month -6 to month -1 ) and the 6 -month window after the closing event month (i.e. from month +1 to month +6 ). Mean and median fund flows are reported as percentage. The p-value tests the hypothesis that the mean/median of pre-close and post-close fund flows is the same.

\begin{tabular}{|c|c|c|c|c|c|c|c|}
\hline & \multirow[t]{2}{*}{$\begin{array}{c}\text { Numbers } \\
\text { of Non- } \\
\text { Closed } \\
\text { Funds }\end{array}$} & \multicolumn{2}{|c|}{$\begin{array}{c}\text { 6-month Pre- } \\
\text { Close Cumulative } \\
\text { Flow \% } \\
\end{array}$} & \multicolumn{2}{|c|}{$\begin{array}{c}\text { 6-month Post- } \\
\text { Close Cumulative } \\
\text { Flow \% } \\
\end{array}$} & \multicolumn{2}{|c|}{$\begin{array}{l}\text { Difference } \\
\text { p value }\end{array}$} \\
\hline & & Mean & Median & Mean & Median & Mean & Median \\
\hline All & 182 & 10.86 & 4.47 & 5.49 & 2.67 & 0.02 & 0.21 \\
\hline Close w/o New Sibling Funds & 129 & 8.94 & 4.46 & 5.30 & 2.40 & 0.16 & 0.38 \\
\hline $\begin{array}{l}\text { Close w/ New Sibling Funds in } \\
\text { Same Objective }\end{array}$ & 38 & 17.68 & 4.36 & 5.67 & 1.64 & 0.01 & 0.17 \\
\hline $\begin{array}{l}\text { Close w/ New Sibling Funds in } \\
\text { Diff Objective }\end{array}$ & 15 & 10.03 & 8.52 & 6.64 & 7.54 & 0.62 & 0.72 \\
\hline
\end{tabular}




\section{Table 9 Logistic Regression Estimates}

At the beginning of each calendar quarter starting from 1995, we collect data on the closed funds' fund level data, their fund family level data, and market condition data. Fund level data includes: prior-quarter-end fund size, priorquarter fund flows, fund age, fund expense ratios, number of managers, average manager tenure, prior-quarter cumulative abnormal returns, and the standard deviation of prior-quarter monthly abnormal returns. Fund family level data includes prior-quarter-end family size, number of objectives in the same family, number of non-closed funds in the same objective as the closed funds in the same family normalized by the average number of funds per investment objective in the fund family, and the prior-quarter asset-weighted non-closed funds' abnormal return in the family. For each fund in each quarter, we exclude values of the specific fund under consideration when we calculate family-level variables. Abnormal returns are size- and objective-adjusted as defined in Table 3 . Market condition data includes the prior-quarter cumulative market excess return (Rm-Rf) and its standard deviation as well as the prior-quarter cumulative objective abnormal return (average objective return - Rm) and its standard deviation. The panel data is constructed by including all closed funds from the quarter they are fully closed till the quarter before they reopen. A mutual fund closes in May and reopens in November in the same year will be included in the $3^{\text {rd }}$ quarter of that year only in the panel data. In Panel A, the dependent variable takes the value one if a closed fund remains closed and the manger(s) launch a sibling fund in a quarter, and zero if a closed fund remains closed and has not launched a sibling fund in a quarter. In Panel B, a multinomial logistic regression is performed. The dependent variable in a given quarter is a set of three choices: a closed fund not launching a new sibling fund, a closed fund launching a new fund in different objective, and a closed fund launching a new fund in the same objective. We report the logistic panel regression estimates, p-value, and odds ratio of the coefficient estimates. The significance level is indicated by the sup-script *** $(1 \%)$, ** $(5 \%)$, and * $(10 \%)$.

Panel A: Among Closed Funds, Launching New Sibling Funds versus Not Launching New Sibling Funds

\begin{tabular}{|c|c|c|c|}
\hline Independent Variables & Estimate & p-value & Odds Ratio \\
\hline \multicolumn{4}{|l|}{ Fund Level } \\
\hline Log(Fund TNA) & $-0.2153^{* * *}$ & 0.00 & 0.81 \\
\hline Prior Quarter Cumulative Fund Flow & $-2.4476^{* * *}$ & 0.00 & 0.09 \\
\hline Fund Age & $0.0169^{* * *}$ & 0.00 & 1.02 \\
\hline Expense Ratio & $-0.5846^{* * *}$ & 0.00 & 0.56 \\
\hline \# of Managers & $0.1054^{* * *}$ & 0.00 & 1.11 \\
\hline Average Manager Tenure & 0.0250 & 0.15 & 1.03 \\
\hline Prior Quarter Cumulative Abnormal Returns & -0.0093 & 0.27 & 0.99 \\
\hline STD(Prior Quarter Cumulative Abnormal Returns) & 0.0354 & 0.23 & 1.04 \\
\hline \multicolumn{4}{|l|}{ Family Level } \\
\hline Log(Family TNA) & $0.1052^{* * *}$ & 0.00 & 1.11 \\
\hline \# of Objectives in Family & $-0.0600^{*}$ & 0.07 & 0.94 \\
\hline $\begin{array}{l}\text { \# of Non-closed Funds in the Same Obj as Closed } \\
\text { Fund / Average \# of Funds per Obj in Family } \\
\text { Prior Ouarter Asset-weighted Non-closed Funds' }\end{array}$ & $-0.5696^{* * *}$ & 0.00 & 0.57 \\
\hline Cumulative Abnormal Returns in Family & 0.0118 & 0.22 & 1.01 \\
\hline \multicolumn{4}{|l|}{ Market Conditions } \\
\hline Prior quarter cumulative (Rm-Rf) & 0.0008 & 0.90 & 1.00 \\
\hline STD(Prior Quarter Cumulative Rm - Rf) & 0.0399 & 0.22 & 1.04 \\
\hline Prior Quarter Cumulative (Obj. Ret - Rm) & 0.0081 & 0.40 & 1.01 \\
\hline STD(Prior Quarter Obj. Ret - Rm) & 0.0018 & 0.95 & 1.00 \\
\hline \multicolumn{4}{|l|}{ Year Fixed Effect Included } \\
\hline \multicolumn{4}{|l|}{ Fund Family Fixed Effect Included } \\
\hline \multicolumn{4}{|l|}{ Adjusted $R^{2}: 0.1071$} \\
\hline \# of Observations: 1818 & & & \\
\hline
\end{tabular}


Table 9-Continued

Panel B: Multinomial Logistic Regression (Reference Category: Not Launching New Sibling Funds)

\begin{tabular}{|c|c|c|c|c|}
\hline \multirow[t]{2}{*}{ Independent Variables } & \multicolumn{2}{|c|}{$\begin{array}{l}\text { Launching New } \\
\text { Sibling Funds in the } \\
\text { Different Objective }\end{array}$} & \multicolumn{2}{|c|}{$\begin{array}{l}\text { Launching New } \\
\text { Sibling Funds in the } \\
\text { Same Objective }\end{array}$} \\
\hline & Estimate & p-value & Estimate & p-value \\
\hline \multicolumn{5}{|l|}{ Fund Level } \\
\hline $\log$ (Fund TNA) & $-0.1351^{* *}$ & 0.03 & $-0.2576^{* * *}$ & 0.00 \\
\hline Prior Quarter Cumulative Fund Flow & $-2.7589^{* * *}$ & 0.00 & $-2.2092^{* * *}$ & 0.00 \\
\hline Fund Age & 0.0062 & 0.33 & $0.0225^{* * *}$ & 0.00 \\
\hline Expense Ratio & $-0.5559^{* * *}$ & 0.01 & $-0.5572^{* * *}$ & 0.00 \\
\hline \# of Managers & $0.2098^{* * *}$ & 0.00 & -0.0073 & 0.85 \\
\hline Average Manager Tenure & -0.0074 & 0.75 & $0.0531^{* * *}$ & 0.01 \\
\hline Prior Quarter Cumulative Abnormal Returns & -0.0113 & 0.28 & -0.0071 & 0.48 \\
\hline STD(Prior Quarter Cumulative Abnormal Returns) & -0.0217 & 0.58 & $0.0789^{* *}$ & 0.02 \\
\hline \multicolumn{5}{|l|}{ Family Level } \\
\hline $\log ($ Family TNA) & 0.0808 & 0.11 & $0.0963^{* *}$ & 0.02 \\
\hline \# of Objectives in Family & -0.0560 & 0.18 & -0.0580 & 0.14 \\
\hline $\begin{array}{l}\text { \# of Non-closed Funds in the Same Obj as Closed } \\
\text { Fund / Average \# of Funds per Obj in Family } \\
\text { Prior Quarter Asset-weighted Non-closed Funds' }\end{array}$ & $-1.1622^{* * *}$ & 0.00 & $-0.1794^{*}$ & 0.10 \\
\hline Cumulative Abnormal Returns in Family & 0.0131 & 0.29 & 0.0103 & 0.37 \\
\hline \multicolumn{5}{|l|}{ Market Conditions } \\
\hline Prior quarter cumulative (Rm-Rf) & 0.0044 & 0.61 & -0.0012 & 0.88 \\
\hline STD(Prior Quarter Cumulative Rm - Rf) & 0.0370 & 0.40 & 0.0456 & 0.22 \\
\hline Prior Quarter Cumulative (Obj. Ret - Rm) & 0.0084 & 0.50 & 0.0090 & 0.42 \\
\hline STD(Prior Quarter Obj. Ret - Rm) & 0.0565 & 0.13 & -0.0508 & 0.22 \\
\hline $\begin{array}{l}\text { Year Fixed Effect Included } \\
\text { Fund Family Fixed Effect Included } \\
\text { Adjusted } R^{2}: 0.1899 \\
\text { \# of Observations: } 1818\end{array}$ & & & & \\
\hline
\end{tabular}

